\title{
Bacterial subclinical mastitis and its effect on milk yield in low-input dairy goat herds
}

\author{
A. I. Gelasakis, ${ }^{* 1}$ A. S. Angelidis, $†$ R. Giannakou, ${ }^{*}$ G. Filioussis, $\ddagger$ M. S. Kalamaki, ${ }^{*}$ and G. Arsenos ${ }^{*}$ \\ *Department of Animal Production, \\ †Laboratory of Milk Hygiene and Technology, Department of Food Hygiene and Technology, and \\ fLaboratory of Microbiology and Infectious Diseases, Department of Infectious, Parasitic Diseases and Pathology, Faculty of Veterinary Medicine, \\ School of Health Sciences, Aristotle University of Thessaloniki, GR 54124, Thessaloniki, Greece
}

\begin{abstract}
The objectives of this study were (1) to record the major pathogens associated with subclinical mastitis (SCM), (2) to calculate their incidence during the milking period, and (3) to estimate the effect of SCM on daily milk yield (DMY) for goats reared under lowinput management schemes. Dairy goats $(\mathrm{n}=590)$ of Skopelos and indigenous Greek breeds from 4 herds were randomly selected for the study. The study included monthly monitoring, milk yield recording, and bacteriological analyses of milk of individual goats during the course of 2 successive milking periods. Incidence and cumulative incidence were calculated for SCM cases. Moreover, 2 mixed linear regression models were built to assess the effects of (1) SCM and (2) different pathogens isolated from SCM cases, on DMY. The estimated incidence and cumulative incidence of SCM for the first and the second year of the study were 69.5 and 96.4 new cases of SCM/1,000 goat-months, and 24.1 and $31.7 \%$, respectively. A total of 755 milk samples were subjected to microbiological examination, resulting in 661 positive cultures. Coagulase-negative and coagulase-positive staphylococci were isolated from 50.2 and $34.5 \%$ of the positive cultures, respectively. The incidence of infections (new infections per 1,000 goat-months) for the first and the second year of the study were 34 and 53 for coagulase-negative staphylococci, 23 and 28 for coagulase-positive staphylococci, 3 and 5 for Streptococcus/Enterococcus spp., and 5.5 and 9.1 for gram-negative bacteria. Goats with SCM had lower DMY when compared with goats without SCM (ca. $47 \mathrm{~g} / \mathrm{d}$, corresponding to a $5.7 \%$ decrease in DMY). In particular, goats with SCM due to coagulase-positive staphylococci infection produced approximately 80 $\mathrm{g} / \mathrm{d}$ less milk (a reduction of ca. 9.7\%) compared with uninfected ones, whereas SCM due to gram-negative
\end{abstract}

Received November 28, 2015.

Accepted January 9, 2016.

${ }^{1}$ Corresponding author: gelasakis@vet.auth.gr bacteria resulted in approximately $15 \%$ reduction in DMY. Investigating the epidemiology of SCM and its effects on production traits is critical for the establishment of effective preventive measures against SCM and for the assessment of the sustainability of production in low-input dairy goat herds.

Key words: subclinical mastitis, milk yield, dairy goat, low-input system

\section{INTRODUCTION}

Subclinical mastitis (SCM) is one of the most challenging diseases in dairy goat herds because it has been linked to production loss, downgrading of milk quality and hygiene, increased replacement cost, and considerable veterinary expenses (Koop et al., 2010). Several environmental and infectious pathogens have been isolated from SCM cases in goats reared under various systems. Coagulase-negative staphylococci and Staphylococcus aureus are frequently isolated from cases of SCM, whereas Streptococcus spp., Pseudomonas aeruginosa, Enterobacteriaceae, Mycoplasma spp., and other pathogens occur at lower frequencies (Contreras et al., 2007). The frequency of isolation of different pathogens from goat herds is strongly related to the herds' overall hygiene status and their general management schemes (McDougall et al., 2002). Regardless of the implemented management system, these practices seem to play a crucial role in the environmental contamination with udder pathogens and the establishment of IMI.

The most prevalent production system in Greece is the low-input, semi-extensive, pastoral system, with goats grazing throughout the year in shrublands and woodlands on semi-mountainous and mountainous areas (Arsenos et al., 2014). The produced milk is often locally used by the farmers for cheese production without pasteurization. Hence, when present in raw milk, intramammary pathogens of public health significance can end up in the final product. This is particularly important in the case of soft cheeses where the absence of ripening or the insufficient degree of ripening may 
render them unsafe for the consumer. Even if milk is pasteurized, the risk of cross contamination during production and handling, as well as the risk from thermostable staphylococcal enterotoxins which can persist in the processed products still exists (Contreras et al., 2003).

In the majority of cases, low-input management schemes in dairy goat herds, which are considered compatible with the principles of organic farming, have not been assessed in terms of goats' udder health status, their productivity, and the hygiene status of the produced milk. Also, the interaction among these factors remains unexplored.

The epidemiology of SCM in low-input dairy goat herds and data regarding the most significant pathogens associated with its incidence are rather scarce. Also, the effect of SCM on milk yield in goats reared under these systems remains unknown. Thus, the objectives of this study were (1) to record the major pathogens associated with SCM, (2) to calculate the incidence of SCM during the milking period, and (3) to estimate the effect of SCM on milk yield of goats reared under low-input management schemes.

\section{MATERIALS AND METHODS}

\section{Animals}

Dairy goats $(\mathrm{n}=590)$ of 2 indigenous Greek breeds (Skopelos and indigenous Greek) from 4 representative herds were randomly selected for the study. The 2 Skopelos goat farms were located at the islands of Skopelos and Alonnisos, whereas the 2 indigenous goat farms were in the regions of Thessaloniki and Serres. The principal characteristics of the goat farms that participated in the study are summarized in Table 1. All of the studied herds followed a low-input pastoral management system, characterized by grazing shrublands and woodlands throughout the year.

\section{Sample Collection and Handling}

The study was a prospective one including monthly monitoring and milk sampling of the same individual goats at weaning and for the next 5 mo during the course of 2 consecutive milking periods. At the commencement of the work, each month, each goat was initially subjected to a detailed clinical and udder examination. Following proper disinfection of the udder of each goat and the withdrawal of the initial 3 to 4 squirts of milk, 2 different milk samples (ca. 50 $\mathrm{mL}$ each), were collected in sterile plastic tubes with lids. The first sample was collected aseptically directly from the udder taking approximately equal volumes from each udder half. The second was a composite milk sample collected from the milking bucket at the end of milking. Milk samples were stored in isothermal containers $\left(2-4^{\circ} \mathrm{C}\right)$, and transferred within $24 \mathrm{~h}$ to the laboratory. The first milk sample was tested for total viable counts (TVC) and the second sample for SCC and lactose content using automatic high-throughput analyzers [Bactoscan FC, Fossomatic FC (Foss) and MilkoScan FT+, respectively].

For both milking periods, and on a monthly basis, each individual goat that produced milk with SCC $>10^{6} / \mathrm{mL}$ and TVC $>2 \times 10^{4} / \mathrm{mL}$ during the preceding sampling was selected for the collection of a third milk sample designated for microbiological analyses. These milk samples, collected aseptically as described above, were transported in isothermal containers within $24 \mathrm{~h}$ to the laboratory for bacteriological examinations. An animal was considered to have SCM each time a pathogen was isolated from its milk during bacteriological testing.

\section{Microbiological Analyses}

Upon arrival to the laboratory, plastic tubes containing aseptically collected milk samples were hand-mixed

Table 1. General characteristics of the farms that participated in the study ${ }^{1}$

\begin{tabular}{|c|c|c|c|c|}
\hline Item & Farm 1 & Farm 2 & Farm 3 & Farm 4 \\
\hline Region & Alonnisos & Thessaloniki & Serres & Skopelos \\
\hline Longitude & $39^{\circ} 12^{\prime} 50$ & $40^{\circ} 46^{\prime} 19$ & $41^{\circ} 00^{\prime} 21$ & $39^{\circ} 04^{\prime} 26$ \\
\hline Latitude & $23^{\circ} 53^{\prime} 27$ & $23^{\circ} 17^{\prime} 22$ & $23^{\circ} 19^{\prime} 37$ & $23^{\circ} 43^{\prime} 39$ \\
\hline Breed & Skopelos & Indigenous Greek & Indigenous Greek & Skopelos \\
\hline Milk production/lactation (kg) & 280 & 180 & 75 & 420 \\
\hline No. of adult goats & 250 & 1200 & 550 & 200 \\
\hline No. of bucks & 20 & 85 & 60 & 25 \\
\hline No. of yearlings & 70 & 215 & 70 & 50 \\
\hline Goat replacement rate (\%) & 15 & 15 & 12 & 25 \\
\hline Cultivated land (ha) & 0 & 385 & 7 & 0 \\
\hline Daily grazing duration $(\mathrm{h} / \mathrm{d})$ & 10 & 6 & 9 & 10 \\
\hline Daily grazing distance $(\mathrm{km} / \mathrm{d})$ & 12 & 10 & 12 & 8 \\
\hline
\end{tabular}

${ }^{1}$ All farms practiced 2 hand-milkings per day. 
and opened in a biosafety level II cabinet. Although there was no history of antibiotic treatment of goats for at least 2 wk before sample collection, all the samples were checked for antimicrobial residues via the application of the Delvotest SP test (DSM Food Specialties, Delft, the Netherlands).

Ten-microliter milk volumes were streaked onto Columbia Agar with Sheep Blood Plus (CASBP, Oxoid Deutschland GmbH, Wesel, Germany) and MacConkey Agar (MCA, Biolife Italiana S.r.l., Milan, Italy) plates and incubated at $37^{\circ} \mathrm{C}$. Plates were examined for microbial growth and checked for purity after 24 to $48 \mathrm{~h}$. In case no growth was visible after the first 24 to 48 $\mathrm{h}$ of incubation, plates were reincubated $\left(37^{\circ} \mathrm{C}\right)$ and rechecked at 24-h intervals for up to $96 \mathrm{~h}$. In addition, upon arrival to the laboratory, $1 \mathrm{~mL}$ of milk from each sample was enriched in $10 \mathrm{~mL}$ of Brain Heart Infusion Broth (Biolife) for $4 \mathrm{~h}$ at $37^{\circ} \mathrm{C}$. Following incubation, $100 \mu \mathrm{L}$ of the Brain Heart Infusion Broth enrichment culture were surface-plated onto a new CASBP plate. The purpose of this enrichment step was to detect pathogens present at low levels (i.e., $<1 \mathrm{cfu} / 10 \mu \mathrm{L}$ ) in the milk samples. Upon initial testing, all milk samples were immediately resealed and transferred in the refrigerator $\left(4 \pm 1^{\circ} \mathrm{C}\right)$.

Isolates from CASBP and MCA plates containing pure cultures (i.e., colonies of the same morphology) as well as isolates from plates containing up to 2 colony types, provided that one of them resembled the morphological characteristics of infectious pathogens (i.e., $S$. aureus or Streptococcus agalactiae), were further characterized. Colony characteristics and hemolysis type $(\alpha, \beta$, or $\gamma)$ or lactose fermentation were recorded for each isolate on CASBP and MCA plates, respectively. Milk samples yielding 3 or more dissimilar colony types on CASBP plates were considered to have originated from contaminated milk samples and were not further analyzed.

Initial analyses of the isolates included (a) Gram staining using standard Gram staining technique and reagents (Merck, Darmstadt, Germany), as well as the Ryu nonstaining $\mathrm{KOH}$ technique (Powers, 1995) and microscopic examination under brightfield illumination at $\times 1,000$, (b) catalase test on glass slides with $3 \%$ hydrogen peroxide solution, and (c) oxidase test using oxidase strips (Bactident Oxidase, Merck).

Gram-negative isolates were re-streaked onto tryptone soya yeast extract agar (TSYEA, Biolife) plates $\left(37^{\circ} \mathrm{C}\right.$ for $\left.24 \mathrm{~h}\right)$ and were subjected to biochemical identification using the API 20E (bioMérieux, Marcy l'Etoile, France) and the RapID ONE System (Remel Inc., Lenexa, KS) miniaturized biochemical test strips.

Gram-positive isolates were further classified into major groups (e.g., coryneforms, staphylococci, strepto- cocci/enterococci) according to their initial biochemical and microscopic characterization data, [i.e., their morphological characteristics (rods vs. cocci), arrangement (e.g., in clumps, chains), and catalase reaction (positive vs. negative) according to the National Mastitis Council guidelines (NMC, 1999)]. A total of 53 atypical gram-positive isolates were additionally subjected to biochemical identification testing using miniaturized biochemical test strips (RapID STAPH PLUS, RapID STR, RapID CB Plus, Remel Inc.).

Among staphylococcal isolates, the distinction between CPS and CNS was performed after assessing coagulase production (a) by streaking the isolates onto Baird-Parker agar with rabbit plasma fibrinogen (Biolife) and incubation at $37^{\circ} \mathrm{C}$ for 24 to $48 \mathrm{~h}$ and (b) by performing the tube coagulase test using lyophilized rabbit plasma (Coagulase Plasma EDTA, Biolife).

In addition, a subset $(\mathrm{n}=154)$ of randomly selected milk samples were examined $(1 \mathrm{~mL})$ qualitatively and quantitatively for Listeria monocytogenes and other Listeria spp. according to ISO 11290-1 and 11290-2, respectively (ISO, 2004a,b) as previously described (Angelidis et al., 2012).

Milk samples yielding no visible growth on either one of the CASBP plates (initial + enrichment plating) after $24 \mathrm{~h}$ of incubation at $37^{\circ} \mathrm{C}$ (a total of 208 milk samples) were removed from the refrigerator and checked for the presence of Mycoplasma spp. using Eatons agar and broth (prepared in the laboratory). Briefly, $0.1 \mathrm{~mL}$ of each milk sample was streaked on Eatons agar (Nicholas and Baker, 1998) and incubated for 3 to $7 \mathrm{~d}$ at $37^{\circ} \mathrm{C}$ in a humidified incubator supplied with $5 \% \mathrm{CO}_{2}$. Meanwhile, $0.5 \mathrm{~mL}$ of each milk sample was incubated in $10 \mathrm{~mL}$ of Eatons broth (Nicholas and Baker, 1998) at $37^{\circ} \mathrm{C}$ aerobically. Broth-to-broth passages and subcultures to agar plates were made twice at 48- to 72-h intervals. Isolates were purified 3 times on solid medium, after which a single colony was selected, transferred to Eatons broth, and incubated aerobically for 2 to $3 \mathrm{~d}$. The DNA extraction from mycoplasma broth cultures was carried out using the QIAmp Tissue kit (Qiagen GmBH, Hilden, Germany) according to the manufacturer's instructions. The DNA samples were analyzed by multiplex PCR using 2 sets of primers, specific for Mycoplasma agalactiae and the Mycoplasma mycoides cluster, respectively (Greco et al., 2001).

\section{Milk Yield Assessment}

Daily milk yield (DMY) was estimated using 1 of the 2 milkings (morning or evening) and adjusting according to International Committee for Animal Recording recommendations (AT4 method). Animals diagnosed with clinical mastitis at the time of sampling 
were excluded from the study. A goat was considered to have SCM on a given sampling/test date, when its milk yielded a positive bacteriological culture on that sampling/test date and the SCC and TVC test results obtained during the previous sampling date were $>10^{6} /$ $\mathrm{mL}$ and $>2 \times 10^{4} / \mathrm{mL}$, respectively.

\section{Statistical Analyses}

Incidence and cumulative incidence were calculated for SCM cases, as well as for individual pathogens or pathogen combinations isolated from the assayed milk samples during the 2 yr of the study. Data were analyzed using SPSS 21; 2 mixed linear regression models were built to assess how DMY was affected by (1) SCM and (2) different pathogens isolated from SCM cases. The first model was used to quantify the effect of SCM, irrespective of the infectious agent, on DMY for the gth sampling occasion, of the hth goat in the ith goat herd $\left(\mathrm{DMY}_{\mathrm{ghi}}\right)$, as described below:

$$
\begin{aligned}
\mathrm{DMY}_{\text {ghi }}= & \mu+\mathrm{SCM}_{\text {ghi }}+\mathrm{K}_{\mathrm{hi}}+\mathrm{P}_{\mathrm{hi}}+\mathrm{G}_{\mathrm{hi}}+\mathrm{Y}_{\text {ghi }} \\
& +\beta_{1} \cdot \mathrm{L}+\gamma_{\mathrm{hi}}+\delta_{\mathrm{i}}+\mathrm{e}_{\text {ghi }}, \quad[\text { model } 1]
\end{aligned}
$$

where $\mu=$ intercept, $\mathrm{SCM}_{\mathrm{ghi}}=$ fixed effect of $\mathrm{SCM}$ status $(2$ levels: $0=$ no $\mathrm{SCM}, 1=\mathrm{SCM}), \mathrm{K}_{\mathrm{hi}}=$ fixed effect of breed (2 levels, $0=$ indigenous Greek breed, 1 $=$ Skopelos breed $), \mathrm{P}_{\mathrm{hi}}=$ fixed effect of parity number (4 levels: 1 st, $2 \mathrm{nd}, 3 \mathrm{rd}$, and $\geq 4$ th parity), $\mathrm{G}_{\mathrm{hi}}=$ fixed effect of sampling time (4 levels: 2nd, 3rd, 4th, and 5th sampling occasion), $\mathrm{Y}_{\text {ghi }}=$ fixed effect of year of the study (2 levels), $\beta_{1}=$ fixed effect of the regression coefficient of the milk lactose concentration $(\mathrm{L}), \gamma_{\mathrm{hi}}=$ repeated variation of the hth goat in the ith herd, $\delta_{i}=$ random variation in the ith herd, and $\mathrm{e}_{\mathrm{ghi}}=$ residual error. Among first-order autoregressive and compound symmetry, the covariance structure with the lowest Akaike's information criterion was included in case a significant improvement of the model was observed $(P$ $<0.05)$.

The second model was used to estimate the effect of SCM, due to different pathogens, on DMY. Model 2 was similar to model 1 , with effects having the same levels. However, model 2 differed on the effect of SCM status that was replaced by the fixed effect of different bacterial groups associated with the occurrence of SCM ( 7 levels: $0=$ absence of SCM, $1=\mathrm{CNS}, 2=$ coagulasepositive staphylococci (CPS), $3=$ streptococci/enterococci, $4=$ gram-negative bacteria, $5=$ Mycoplasma spp., $6=$ unclassified gram-positive bacteria, $7=$ no microbial isolation after culture; model 2). Cured animals were assigned to level 0 (absence of SCM), whereas goats chronically infected or reinfected with the same or other pathogen were assigned either to the initial or to another bacterial group for each sampling occasion, separately. The assumptions of homoscedasticity, normal distribution, and linearity for the models were checked by visually assessing the plots of standardized residuals against standardized predicted values and histograms, as well as the probability-probability and quantile-quantile plots of standardized residuals.

\section{RESULTS}

\section{Descriptive Statistics}

Table 1 presents the general characteristics of the farms involved in the study. In these farms, the estimated incidence of SCM for the first and the second year of sampling was 69.5 and 96.4 new cases of SCM per 1,000 goat-months, respectively. Moreover, the estimated cumulative incidence of SCM was 24.1 and $31.7 \%$, respectively, for the 2 successive years.

During the study, a total of 755 out of 4,576 milk samples $(16.5 \%)$ were subjected to microbiological examination according to the predefined criteria. All samples tested negative for the presence of antibiotic residues. In 167 out of 755 samples $(22.1 \%)$, the cultures were negative, whereas in 33 samples $(4.4 \%)$, more than 2 bacterial types were isolated and therefore these samples were excluded from further analyses. From the remaining 555 positive samples, 661 isolates were obtained: $449(80.9 \%)$ samples yielded a single pathogen and $106(19.1 \%)$ samples yielded 2 different pathogens. Table 2 summarizes the isolated pathogens from the 4 studied herds during the 2 years of the study. The majority of the isolates $(90.0 \%)$ were gram-positive bacteria. Eighteen of the 53 gram-positive isolates $(2.7 \%$ of the total isolates) that presented atypical morphological characteristics (i.e., they were either cocobacilli or unusually large-shaped cocci) could not be identified to the species level after additional biochemical testing, and were therefore characterized as unclassified grampositive. Listeria spp. were not detected in any of the 154 milk samples analyzed. The groups of pathogens isolated from the assayed milk samples are described below.

Coagulase-Negative Staphylococci. Among grampositive bacteria, CNS were the group encompassing the majority of the isolates; CNS represented 332 out of the $661(50.2 \%)$ total isolates (Table 2$)$. Table 3 presents the incidence and cumulative incidence of SCM associated with either single- or dual-pathogen combined infections. Subclinical mastitis due to single-pathogen CNS infections had the highest incidence (ca. 34 and 53 new infections $/ 1,000$ goat-months for the first and the second year, respectively). Subclinical mastitis cases 
Table 2. Pathogen groups and their isolation rates (\%) from goat milk samples from herds 1, 2, 3, and 4 and total for the 2 yr of the study

\begin{tabular}{|c|c|c|c|c|c|c|}
\hline Pathogen group & Year & Herd 1 & Herd 2 & Herd 3 & Herd 4 & Total \\
\hline \multirow[t]{3}{*}{ CNS } & 1 & $18(48.6)$ & $28(40.6)$ & $31(40.3)$ & $49(59.8)$ & \\
\hline & 2 & $21(41.2)$ & $35(55.6)$ & $62(53.4)$ & $88(53.0)$ & \\
\hline & Total & $39(44.3)$ & $63(47.7)$ & $93(48.2)$ & $137(55.2)$ & $332(50.2)$ \\
\hline \multirow{2}{*}{ Coagulase-positive staphylococci } & 2 & $16(31.4)$ & $9(14.3)$ & $45(38.8)$ & $65(39.2)$ & \\
\hline & Total & $25(28.4)$ & $19(14.4)$ & $87(45.1)$ & $97(39.1)$ & $228(34.5)$ \\
\hline Streptococcus/Enterococcus spp. & 1 & $4(10.8)$ & $8(11.6)$ & $1(1.3)$ & $1(1.2)$ & \\
\hline \multirow{2}{*}{ Gram-negative } & 2 & $9(17.6)$ & $10(15.9)$ & $1(0.9)$ & $7(4.2)$ & \\
\hline & Total & $11(12.5)$ & $18(13.6)$ & $4(2.1)$ & $7(2.8)$ & $40(6.1)$ \\
\hline \multirow[t]{3}{*}{ Mycoplasma agalactiae } & 1 & $1(2.7)$ & $5(7.2)$ & $0(0.0)$ & $0(0.0)$ & \\
\hline & 2 & $0(0.0)$ & $0(0.0)$ & $1(0.9)$ & $1(0.6)$ & \\
\hline & Total & $1(1.1)$ & $5(3.8)$ & $1(0.5)$ & $1(0.4)$ & $8(1.2)$ \\
\hline Unclassified gram-positive & 1 & $3(8.1)$ & $10(14.5)$ & $0(0.0)$ & $0(0.0)$ & \\
\hline
\end{tabular}

due to dual-pathogen infections were less frequently observed, the commonest being the combination of 2 different CNS isolates (4 and 10 new infections/1,000 goat-months for the first and the second year, respectively). The cumulative incidence of SCM due to single and dual-isolate CNS infections was 11.9 and $1.5 \%$ for the first and 19.2 and $4.1 \%$ for the second year of the study, respectively.

Coagulase-Positive Staphylococci. Coagulasepositive staphylococci were the second more frequently detected group of gram-positive bacteria and represented 228 out of the $661(34.5 \%)$ isolates (Table 2).

Table 3. Epidemiological characteristics of intramammary infections in the studied herds ${ }^{1}$

\begin{tabular}{|c|c|c|c|c|}
\hline Group of pathogens & $\begin{array}{l}\text { New } \\
\text { infections }\end{array}$ & $\begin{array}{l}\text { Goat-months } \\
\text { at risk }\end{array}$ & $\begin{array}{c}\text { Incidence } \\
\text { (/1,000 goat-months })\end{array}$ & $\begin{array}{c}\text { Cumulative } \\
\text { incidence (\%) }\end{array}$ \\
\hline \multicolumn{5}{|l|}{ Year $1\left(\mathrm{n}_{1}=589\right.$ goats $)$} \\
\hline $\mathrm{CNS}^{2}$ & 70 & 2,064 & 33.9 & 11.9 \\
\hline $\mathrm{CPS}^{2}$ & 47 & 2,074 & 22.7 & 8.0 \\
\hline $\mathrm{S} / \mathrm{E}^{2}$ & 7 & 2,194 & 3.2 & 1.2 \\
\hline Gram-negative $^{2}$ & 10 & 2,176 & 4.6 & 1.7 \\
\hline Mycoplasma agalactiae ${ }^{2}$ & 7 & 2,191 & 3.2 & 1.2 \\
\hline $\mathrm{CNS}^{-\mathrm{CNS}^{3}}$ & 9 & 2,189 & 4.1 & 1.5 \\
\hline${\mathrm{CNS}-\mathrm{CPS}^{3}}^{2}$ & 4 & 2,200 & 1.8 & 0.7 \\
\hline CNS-S/E ${ }^{3}$ & 4 & 2,198 & 1.8 & 0.7 \\
\hline $\mathrm{CPS}-\mathrm{CPS}^{3}$ & 6 & 2,186 & 2.7 & 1.0 \\
\hline \multicolumn{5}{|l|}{ Year $2\left(\mathrm{n}_{2}=590\right.$ goats $)$} \\
\hline $\mathrm{CNS}^{2}$ & 113 & 2,126 & 53.2 & 19.2 \\
\hline $\mathrm{CPS}^{2}$ & 61 & 2,202 & 27.7 & 10.3 \\
\hline $\mathrm{S} / \mathrm{E}^{2}$ & 12 & 2,345 & 5.1 & 2.0 \\
\hline Gram-negative $^{2}$ & 21 & 2,342 & 9.0 & 3.6 \\
\hline Mycoplasma agalactiae $^{2}$ & 1 & 2,367 & 0.4 & 0.2 \\
\hline $\mathrm{CNS}^{-} \mathrm{CNS}^{3}$ & 24 & 2,327 & 10.3 & 4.1 \\
\hline${\mathrm{CNS}-\mathrm{CPS}^{3}}^{3}$ & 9 & 2,346 & 3.8 & 1.5 \\
\hline CNS-S $/ E^{3}$ & 7 & 2,362 & 3.0 & 1.2 \\
\hline CNS gram-negative $^{3}$ & 5 & 2,354 & 2.1 & 0.8 \\
\hline $\mathrm{CPS}^{-\mathrm{CPS}^{3}}$ & 12 & 2,350 & 5.1 & 2.0 \\
\hline CPS-S/E ${ }^{3}$ & 1 & 2,366 & 0.4 & 0.2 \\
\hline CPS gram-negative ${ }^{3}$ & 2 & 2,368 & 0.8 & 0.3 \\
\hline Gram-negative $\mathrm{S} / \mathrm{E}^{3}$ & 2 & 2,367 & 0.8 & 0.3 \\
\hline
\end{tabular}


In herd 3, CPS were the most common bacterial group isolated from cases of SCM during the first year of the study. The incidence of SCM due to CPS infections were approximately 23 and 28 new infections/1,000 goat-months, whereas the cumulative incidence was 8.0 and $10.3 \%$, for the first and the second year, respectively. Dual CPS isolate infections were more frequently detected compared with combined CNS-CPS infections during both years of the study (ca. 3 and 5 new infections/1,000 goat-months for CPS-CPS infections versus approximately 2 and 4 new infections/1,000 goat-months for CPS-CNS infections).

Streptococcus/Enterococcus spp. Streptococcus/ Enterococcus spp. (S/E) represented 35 out of the 661 $(5.3 \%)$ isolates. The incidence of infections with $\mathrm{S} / \mathrm{E}$ was approximately 3 and 5 new infections/1,000 goatmonths for the first and the second year, respectively, with the respective cumulative incidence being approximately 1 and $2 \%$, respectively. The S/E dual infections included mainly other minor pathogens such as CNS (11 cases) rather than major pathogens such as CPS or gram-negative bacteria (3 cases).

Gram-Negative Bacteria. Gram-negative bacteria constituted 40 out of the $661(6.1 \%)$ isolates. Thirtyone out of 40 gram-negative pathogens were present in the respective milk samples as pure cultures and the rest $(\mathrm{n}=9)$ as a mixture of 2 pathogens (combined with a gram-positive pathogen). Table 4 presents the gram-negative bacteria that were isolated and identified to the genus or species level (with a \% of identification by the miniaturized biochemical identification assays $\geq 97 \%$ ) from the assayed milk samples. The most common pathogens in this category were Escherichia coli, Pseudomonas aeruginosa, Citrobacter koseri, and Klebsiella oxytoca, which represented $55 \%$ of the gramnegative bacterial isolates. It is noteworthy that one isolate was identified as Stenotrophomonas maltophilia. Incidence of IMI due to gram-negative bacteria was 5.5 and 9.0 new infections/1,000 goat-months for the first and the second year, respectively. Dual infections by gram-negative bacteria combined with other pathogens were found only in the second year of the study and their incidence ranged from 0.8 to 2.1 new infections $/ 1,000$ goat-months, depending on the combination of pathogens (Table 3).

Mycoplasma spp. Mycoplasma spp. were isolated in 8 out of the 208 samples tested. The expected $375-$ bp product specific for the P80 lipoprotein gene of $M$. agalactiae was amplified from all DNA samples. Consequently, the 8 field isolates were confirmed to belong to this species. Their incidence was approximately 3.0 and 0.5 new infections $/ 1,000$ goat-months for the first and the second year, respectively (Table 3 ).

\section{Effects of SCM and Other Factors on DMY}

The most appropriate covariance structure for the 2 models was the first-order autoregressive model. Table 5 summarizes the fixed effects of the independent variables forced into model 1 ; all of them were statistically significant at $\alpha=0.001$, except for SCM that was significant at $\alpha=0.01$. Goats without SCM had significantly higher DMY (ca. $825 \mathrm{~g} / \mathrm{d}$ ) compared with goats with SCM (a difference of ca. $47 \mathrm{~g} / \mathrm{d}$, corresponding to $5.7 \%$ decreased DMY for infected goats). Moreover, significantly lower DMY was observed for indigenous Greek goats (a reduction of ca. $585 \mathrm{~g} / \mathrm{d}$ ) in comparison to Skopelos goats (ca. 1,065 g/d). Also, the DMY was significantly lower for the fifth month of the milking period (ca. $534 \mathrm{~g} / \mathrm{d}$ ) when compared with the second, third, and fourth month (a reduction of ca. 504, 398, and $146 \mathrm{~g} / \mathrm{d}$, respectively). As calculated by the model, fourth-parity goats had significantly higher DMY $(989 \mathrm{~g} / \mathrm{d})$ compared with first- and second-parity goats (increased by ca. 463 and $262 \mathrm{~g} / \mathrm{d}$, respectively) but not compared with third-parity goats (increased by ca. $45 \mathrm{~g} / \mathrm{d}$ ). In the first year of the study, the DMY was significantly lower compared with the second year by $63.5 \mathrm{~g} / \mathrm{d}$, given that all the other parameters remained constant. Finally, lactose concentration had a significant positive correlation with DMY; for each unit that the lactose concentration increased, an increase of approximately $200 \mathrm{~g} / \mathrm{d}$ in milk yield occurred.

\section{Pathogen-Specific Effects on Milk Yield}

As shown in Table 6, infections with CPS and gramnegative bacteria were found to have a significant

Table 4. Gram-negative bacteria isolated from the milk of goats with subclinical mastitis

\begin{tabular}{|c|c|c|}
\hline Genus or species & $\begin{array}{l}\text { Number } \\
\text { of isolates }\end{array}$ & $\%$ \\
\hline Escherichia coli & 7 & 17.5 \\
\hline Pseudomonas aeruginosa & 6 & 15.0 \\
\hline Citrobacter koseri & 5 & 12.5 \\
\hline Klebsiella oxytoca & 4 & 10.0 \\
\hline Pantoea spp. & 2 & 5.0 \\
\hline Pasteurella haemolytica & 2 & 5.0 \\
\hline Enterobacter spp. & 2 & 5.0 \\
\hline Acinetobacter calcoaceticus & 1 & 2.5 \\
\hline Burkholderia cepacia & 1 & 2.5 \\
\hline Salmonella spp. & 1 & 2.5 \\
\hline Stenotrophomonas maltophilia & 1 & 2.5 \\
\hline Pseudomonas fluorescens & 1 & 2.5 \\
\hline Serratia marcescens & 1 & 2.5 \\
\hline Unidentified $^{1}$ & 6 & 15.0 \\
\hline Total & 40 & \\
\hline
\end{tabular}

${ }^{1}$ Gram-negative isolates with "unacceptable" identification based on the API 20E and RapID One test kits. 
Table 5. Effects of subclinical mastitis and the rest of the parameters forced into model 1 on daily milk yield in the studied goat population ${ }^{1}$

\begin{tabular}{|c|c|c|c|c|c|c|}
\hline Parameter & Category level & $\beta$ & $\mathrm{SE}$ & $P$-value & \multicolumn{2}{|c|}{$95 \%$ CI } \\
\hline Subclinical mastitis & $\begin{array}{l}\text { No } \\
\text { Yes }\end{array}$ & $\begin{array}{l}46.6 \\
\text { Ref }\end{array}$ & 17.8 & 0.009 & 11.8 & 81.5 \\
\hline Breed & $\begin{array}{l}\text { Skopelos } \\
\text { Autochthonous }\end{array}$ & $\begin{array}{l}584.4 \\
\text { Ref }\end{array}$ & 34.4 & 0.000 & 516.9 & 652.0 \\
\hline Month of milking period & $\begin{array}{l}\text { 2nd } \\
3 \text { rd } \\
4 \text { th } \\
5 \text { th }\end{array}$ & $\begin{array}{c}504.3 \\
398.4 \\
146.2 \\
\text { Ref }\end{array}$ & $\begin{array}{l}12.3 \\
11.8 \\
12.1\end{array}$ & $\begin{array}{l}0.000 \\
0.000 \\
0.000\end{array}$ & $\begin{array}{l}480.2 \\
375.3 \\
122.5\end{array}$ & $\begin{array}{l}528.4 \\
421.5 \\
170.0\end{array}$ \\
\hline Parity number & $\begin{array}{l}1 \\
2 \\
3 \\
\geq 4\end{array}$ & $\begin{array}{c}-462.8 \\
-262.3 \\
-45.0 \\
\text { Ref }\end{array}$ & $\begin{array}{r}109.5 \\
49.5 \\
28.5\end{array}$ & $\begin{array}{l}0.000 \\
0.000 \\
0.114\end{array}$ & $\begin{array}{l}-677.6 \\
-357.5 \\
-100.8\end{array}$ & $\begin{array}{r}-247.9 \\
-167.2 \\
10.8\end{array}$ \\
\hline Year of study & $\begin{array}{l}\text { 1st } \\
\text { 2nd }\end{array}$ & $\begin{array}{l}-63.5 \\
\text { Ref }\end{array}$ & 15.3 & 0.000 & -93.5 & -33.4 \\
\hline
\end{tabular}

${ }^{1} \beta=$ coefficient; Ref $=$ reference category.

negative effect on DMY. Namely, a goat with SCM due to CPS produced approximately $80 \mathrm{~g} / \mathrm{d}$ less milk (a reduction of ca. $9.7 \%$ ) compared with a healthy one ( $P$ $=0.009$ ). Similarly, a goat infected with gram-negative bacteria produced approximately $124 \mathrm{~g} / \mathrm{d}$ less milk (a reduction of ca. $15 \%, P=0.031$ ). On the other hand, infections with CNS, S/E, and Mycoplasma spp. were not found to have any significant negative effect on DMY (Table 6).

\section{DISCUSSION}

\section{Descriptive Statistics}

Low-input goat farming systems are distinct in terms of management, productivity, and hygiene status of the animals. In our study, the identification of the most prevalent groups of pathogens associated with SCM, the incidence of SCM, as well as its effect on milk yield, was attempted for the first time for these husbandry systems. As expected, peculiarities were observed in the studied herds in terms of the occurrence of various groups of pathogens and their isolation frequencies, when compared with high-input systems, which were mainly determined by the overall herds' hygiene status and the implemented management practices regarding housing and milking. In particular, in the studied herds, bedding was not used for housing, and the standard practice for disinfection was once per year. Moreover, in all herds hand-milking was practiced and no specific program was in place for the control of IMI (e.g., teat dipping, intramammary antibiotic treatments during dry period, routine California mastitis testing) as is usually the case in high-input goat herds. Differences were also observed between the herds; culling of goats with chronic SCM and the overall replacement rate differed remarkably; herd 1 had the highest culling and replacement rate, which could be associated with the lowest incidence of SCM among the other herds. Moreover, housing conditions including stocking density

Table 6. Daily milk yield (DMY; g/d) of healthy goats $(824.8 \mathrm{~g} / \mathrm{d})$ and goats with subclinical mastitis (SCM) due to infection with different pathogens and the pairwise comparisons between them

\begin{tabular}{|c|c|c|c|c|c|c|}
\hline SCM pathogen $^{1}$ & $\begin{array}{l}\text { DMY } \\
(\mathrm{g} / \mathrm{d})\end{array}$ & $\begin{array}{l}\text { Mean difference } \\
\text { of } \mathrm{DMY}^{2}(\mathrm{~g} / \mathrm{d})\end{array}$ & $\mathrm{SE}$ & $P$-value & \multicolumn{2}{|c|}{$95 \% \mathrm{CI}$} \\
\hline CNS & 796.6 & -28.2 & 23.7 & 0.233 & -74.3 & 18.2 \\
\hline $\mathrm{S} / \mathrm{E}$ & 762.5 & -62.3 & 72.9 & 0.393 & -205.3 & 80.7 \\
\hline Gram-negative & 701.2 & -123.6 & 57.3 & 0.031 & -236.0 & -11.2 \\
\hline Mycoplasma agalactiae & 731.4 & -93.4 & 121.0 & 0.440 & -330.6 & 143.7 \\
\hline
\end{tabular}

${ }^{1} \mathrm{CPS}=$ coagulase-positive staphylococci; $\mathrm{S} / \mathrm{E}=$ Streptococcus/Enterococcus $\mathrm{spp}$.

${ }^{2}$ Compared with healthy goats. 
and ventilation were dissimilar, albeit insufficient in all cases.

The SCM prevalence was the lowest in primiparous goats and increased by parity. Similar results have been reported by Moroni et al. (2005a), who hypothesized that chronic IMI, which failed to be eliminated during the dry period, could partially explain this increase on SCM prevalence in $>1$ st parity does. This could be the case for the studied herds because there was no treatment of goats with intramammary antibiotics during the dry period to reduce the occurrence of persistent IMI. Persistent infections could also explain why the prevalence of SCM was found to be higher at later stages of the milking period rather than at the beginning, as also observed by Moroni et al. (2005a) in Italian dairy goat herds.

In our study, the thresholds beyond which milk samples were microbiologically assessed was set to $>10^{6}$ cells $/ \mathrm{mL}$ and $2 \times 10^{4} \mathrm{cfu} / \mathrm{mL}$ for $\mathrm{SCC}$ and TVC, respectively. Using these thresholds, the overall proportion of samples that yielded negative cultures was approximately $22.0 \%$.

Up to now, no universal definition has been found of the SCC threshold to distinguish between infected and healthy mammary glands in dairy goats, and with respect to TVC, little is known regarding the threshold beyond which SCM is likely to occur (Chiang et al., 2010; Stuhr and Aulrich, 2010). In particular, setting out a SCC threshold for the diagnosis of SCM in goats is an issue of debate among researchers, with most of them suggesting either $5 \times 10^{5}$ cells $/ \mathrm{mL}$, or $10^{6}$ cells $/ \mathrm{mL}$ as the most appropriate threshold (Koop et al., 2011). The main reason for this debate is the considerable differences regarding the usefulness of the 2 aforementioned thresholds for the diagnosis of SCM as observed by several research groups and reviewed by Koop et al. (2011). In general, using a lower threshold increases the sensitivity but decreases the specificity of the SCC test, with the opposite being observed when the threshold is set to a higher value. Additionally, apart from IMI, other noninfectious factors may be associated with an increase in the number of somatic cells in the milk (parity, stage of lactation, estrous, stress, breed). This questions the usefulness of SCC as a tool for the accurate diagnosis of SCM in goats. Given the aforementioned facts, in our study we chose to use a "high," predefined SCC limit to select animals infected by pathogens causing a more profound reaction of the immune system and apoptosis of epithelial cells, and on the same time avoid having to test milk samples more likely to be culture negative. The other reason we chose this SCC limit is that it coincides with the scores 2 and 3 in the 5 -score scale (N, T, 1, 2, and 3 ) of the California Mastitis Test, which is a cheap and commercially available test for on-farm assessment of SCM. The latter helps goat farmers having an indication of the negative effect of SCM on milk production of their herd. Hence, the ease and practicality of the methodology facilitates the farmer's decision regarding cost-effectiveness of preventive measures against SCM.

\section{Pathogens Associated with SCM}

In all 4 herds studied, CNS were found to be the most frequently detected pathogens from cases of SCM, confirming past observations made by other research groups in intensively reared dairy goat herds (Contreras et al., 2007; Leitner et al., 2007; McDougall et al., 2014). The CNS are considered environmental pathogens. Therefore, it could be speculated that, in the majority of cases, infections with CNS originated from poor housing conditions (i.e., insufficient bedding) and inappropriate milking practices or other management defaults as described earlier.

The CPS were the second most frequently isolated group of pathogens from goats with SCM. Coagulasepositive staphylococci are major pathogens associated both with clinical and SCM, depending on the bacterial strain and the severity of infection. Among the different CPS species, S. aureus is considered as the most infectious agent leading to subclinical, chronic, or severe gangrenous IMI (White and Hinckley, 1999). Although identification of CPS at the species level was not performed in this study, the isolation frequency was higher in comparison to the majority of studies in the available literature (Contreras et al., 2003, 2007; Virdis et al., 2010). Inappropriate hygiene during hand-milking could lead to the horizontal transmission of CPS within the herd via the hands of milkers.

In previous studies, the prevalence of Streptococcus spp. isolated from caprine IMI ranged from 4 to $10 \%$ (White and Hinckley, 1999; Contreras et al., 2003). In our study, both the incidence and the cumulative incidence of $\mathrm{S} / \mathrm{E}$ infections were rather low. In this pathogen group, single-pathogen infections and infections combined with other pathogen groups did not differ remarkably regarding their incidence (Table 3). Among S/E combined infections, those involving other minor pathogens (CNS) were more frequently observed, indicating the environmental origin of these infections.

Subclinical mastitis due to gram-negative bacteria rarely occurs in goats (Contreras et al., 1995, White and Hinckley, 1999), which is in accordance with our findings. In some cases, these infections coexist with other systemic diseases. However, clinical examination of intramammary infected goats in our study failed to reveal any symptoms of systemic infections due to this group of pathogens. 
The incidence of Mycoplasma spp. was rather low. However, this can be attributed to the exclusion of goats diagnosed with clinical mastitis; Mycoplasma spp. are well-known agents involved in clinical mastitis episodes in dairy goats (Contreras et al., 2003). In addition, among the assayed milk samples, only those with negative bacterial cultures at $24 \mathrm{~h}$ of incubation were used for the detection of Mycoplasma spp. Hence, it is likely that the incidence would have been higher had all samples been examined for the presence of Mycoplasma spp.

In our study, a possible antagonistic activity of minor pathogens (i.e., CNS) against major pathogens (i.e., CPS and gram-negative bacteria) in combined infections, as in the case of cows (Rainard and Poutrel 1988; Lam et al., 1997), could be assumed based on the fact that combined IMI more frequently involved 2 different minor (i.e., CNS-CNS and CNS-S/E) or major pathogens (i.e., CPS-CPS), rather than one minor and one major pathogen (i.e., CPS-CNS and CPS-S/E).

\section{Public Health Relevance}

Unpasteurized milk and cheeses made from unpasteurized milk have been frequently implicated in foodborne illness (Gould et al., 2014; EFSA Panel on Biological Hazards, 2015). Therefore, the isolation and identification of pathogenic bacteria from milk of animals with SCM is important.

Among the groups of bacteria isolated in our study, CPS (e.g., S. aureus) are capable of producing heatstable enterotoxins, whereas members of the group often carry antibiotic resistance genes (Valle et al., 1990; Moroni et al., 2005b; Virdis et al., 2010). In the past, pathogenic streptococci have been implicated in outbreaks of foodborne infections after consumption of unpasteurized cow milk (Bryan, 1983; Edwards et al., 1988).

Among the gram-negative bacteria isolated in our study, Pseudomonas aeruginosa and Salmonella spp. have been associated with milk-borne illness (Desenclos et al., 1996). One of the gram-negative isolates was identified as S. maltophilia. Stenotrophomonas maltophilia is a microorganism intrinsically resistant to most currently available broad-spectrum antimicrobials and has recently risen to prominence as a causative agent of opportunistic infections (Albini et al., 2009). Although S. maltophilia has been considered an infrequent cause of clinical mastitis in dairy cows (Ohnishi et al., 2012; Zhang et al., 2015), to our knowledge, it has not been previously isolated from small ruminant SCM cases. Thus, unhygienic milking practices and consumption of unpasteurized goat milk (products) can be considered as a way of human acquisition of $S$. maltophilia.
Isolation of Listeria spp. from goat milk is rarely reported (Bergonier et al., 2003). In our study, Listeria spp. were not isolated from mastitic milk. Absence of pathogenic Listeria spp. (L. monocytogenes and L. ivanovii) from the assayed samples is an important finding with respect to both the safety of the produced dairy products and the health of goats (Oliver et al., 2005).

\section{Effect of SCM on Milk Yield}

In our study, the hypothesized negative effect of SCM on milk yield was estimated for the first time in lowinput goat farming systems. In general, milk yield in the studied goat population was rather low. This is common in low-input pastoral systems, where animals are expected to meet their nutritional demands by grazing into less favorable areas of shrublands throughout the year. Given the implemented farming system, only herd \#4 was found to be exceptionally high producing, which could be explained by the plethora of natural resources available during grazing at this location (grassland). Hence, to avoid confounding, the developed model was adjusted for the random effect of the selected herds.

In general, quantifying milk loss due to SCM is a complicated task, irrespective of the implicated pathogen. In the past, studies on the effect of IMI on milk yield under intensive management systems have produced controversial results. Hence, IMI have been associated with lower (Leitner et al., 2004), equal (Moroni et al., 2005a; Min et al., 2007), or even higher milk yield (Koop et al., 2012) in the infected goats in comparison to uninfected ones. Therefore, it was concluded that IMI with different pathogens show a remarkable variation regarding the effect size (either positive or negative) on milk yield (Koop et al., 2012). It seems that the effect of CNS infections level out when CNS are considered as a group of pathogens rather than individual species (Koop et al., 2012). This could also be the case for CPS. Koop et al. (2010) studied the negative effect of IMI due to various pathogens and found a significant production loss when the udder was infected with CPS and gram-negative bacteria, but not in cases of infection with environmental pathogens, such as CNS. The aforementioned observations are in complete agreement with the findings of our study, where CPS and gram-negative bacterial infections were associated with a remarkable milk loss, whereas CNS infections had no negative effect on DMY. Studies on dairy ewes (Gelasakis et al., 2015) and cows (Schukken et al., 2009) have also produced similar results. The significant milk losses due to infections with major pathogens could be attributed to the more extensive and severe damages to the mammary gland, resulting in a partial loss of its functionality (Contreras et al., 
2003). On the other hand, the damages to the mammary gland and the inflammatory response due to infections with minor pathogens are not considered to be severe, and this could partially explain the insignificant effects of these pathogens on milk yield. In any case, the pathogenetic process during IMI with various pathogens (either minor or major) leading to damages of the mammary gland and milk yield reduction remain largely unknown and form an interesting research field for future investigation (Contreras et al., 2007).

According to other theories formulated by Koop et al. (2012), the absence of significant effects of CNS infections on milk yield could be attributed to the higher risk of high-milk-yielding goats of being infected by minor pathogens (including CNS), or to the antagonistic activity of minor pathogens against major pathogens associated with SCM (Lam et al., 1997). Considering the first theory, the higher susceptibility of high-milk yielders to SCM can result in milk loss. Nonetheless, the milk yield of a SCM-infected, high-milk yielder is still likely to remain at higher levels compared with that of uninfected, average-milk yielders in the same herd. This provides a reasonable explanation on how, in some cases, goats with subclinical IMI have been found to have higher or similar milk yield when compared with healthy goats. To address this hypothesis, Leitner et al. (2004) investigated the effect of IMI at the goat level by infecting only one-half of the udder of 36 goats. The authors confirmed a significantly lower milk yield for the infected half in comparison to the healthy one. According to the second theory, the occurrence of a possible antagonistic relationship between minor and major pathogens could be linked to decreased bioactivity of major pathogens and consequently to a smaller effect on udder health and milk yield.

In conclusion, the present study showed a remarkable incidence of subclinical IMI in low-input dairy goat herds. Those IMI resulted in a significant milk yield reduction for the infected goats. Among the isolated pathogens, CPS and gram-negative bacterial IMI were found to be associated with the most significant losses in milk production.

\section{ACKNOWLEDGMENTS}

The research leading to these results has received funding from the European Community's Seventh Framework Programme (FP7/2007-2013) under the grant agreement $n^{\circ}$ FP7-266367 (SOLID). The authors acknowledge the dairy company Mevgal for aiding with milk chemical analyses. Also, S. Termatzidou, A. Soufleri (PhD candidates), M. Karatzia (postdoctoral researcher), and P. Kazana (resident student) from the Department of Animal Production, Faculty of Vet- erinary Medicine, School of Health Sciences, Aristotle University of Thessaloniki, Greece are acknowledged for their contribution during sampling and data collection. Finally, we strongly acknowledge the participating farmers Eyaggelos Pachis (Skopelos), Giorgos Athanasiou (Alonnisos), Dimitris Chatzipapadopoulos (Thessaloniki), and Panagiotis Kechagias (Serres) for their sincere collaboration throughout the study.

\section{REFERENCES}

Albini, S., C. Abril, M. Franchini, D. Hussy, and G. Filioussis. 2009. Stenotrophomonas maltophilia isolated from the airways of animals with chronic respiratory disease. Schweiz. Arch. Tierheilkd. 151:323-328.

Angelidis, A. S., S. S. Georgiadou, V. Zafeiropoulou, E. N. Velonakis, D. K. Papageorgiou, and A. Vatopoulos. 2012. A survey of soft cheeses in Greek retail outlets highlights a low prevalence of Listeria spp. Dairy Sci. Technol. 92:189-201.

Arsenos, G., A. I. Gelasakis, S. Pinopoulos, R. Giannakou, and I. Amarantidis. 2014. Description and typology of dairy goat farms in Greece. Eprint ID 23913 in Proc. 4th ISOFAR Scientific Conference. "Building Organic Bridges" at the Organic World Congress 2014, 13-15 October, Istanbul, Turkey. G. Rahmann and U. Aksou, ed. IFOAM-Organics International, Bonn, Germany

Bergonier, D., R. de Crémoux, R. Rupp, G. Lagriffoul, and X. Berthelot. 2003. Mastitis of dairy small ruminants. Vet. Res. 34:689-716.

Bryan, F. L. 1983. Epidemiology of milk-borne diseases. JFP 46:637649 .

Chiang, C. C., C. J. Chang, H. C. Peh, S. E. Chen, B. Yu, M. T. Chen, and H. Nagahata. 2010. Calcium homeostasis and its relationship to superoxide production in blood and milk neutrophils of lactating goats. Vet. Immunol. Immunopathol. 133:125-132.

Contreras, A., J. C. Corrales, D. Sierra, and J. Marco. 1995. Prevalence and aetiology of non-clinical intramammary infection in Murciano-Granadina goats. Small Rumin. Res. 17:71-78.

Contreras, A., C. Luengo, A. Sánchez, and J. C. Corrales. 2003. The role of intramammary pathogens in dairy goats. Livest. Prod. Sci. $79: 273-283$.

Contreras, A., D. Sierra, A. Sánchez, J. C. Corrales, J. C. Marco, M. J. Paape, and C. Gonzalo. 2007. Mastitis in small ruminants. Small Rumin. Res. 68:145-153.

Desenclos, J. C., P. Bouvet, E. Benz Lemoine, F. Grimont, H. Desqueyroux, I. Rebière, and P. A. D. Grimont. 1996. Large outbreak of Salmonella enterica serotype paratyphi $B$ infection caused by a goats' milk cheese, France, 1993: A case finding and epidemiological study. BMJ 312:91-94.

Edwards, A. T., M. Roulson, and M. J. Ironside. 1988. A milk-borne outbreak of serious infection due to Streptococcus zooepidemicus (Lancefield Group C). Epidemiol. Infect. 101:43-51.

EFSA Panel on Biological Hazards. 2015. Scientific opinion on the public health risks related to the consumption of raw drinking milk. EFSA J. 13:3940.

Gelasakis, A. I., V. M. Mavrogianni, I. G. Petridis, N. G. C. Vasileiou, and G. C. Fthenakis. 2015. Mastitis in sheep-The last 10 years and the future of research. Vet. Microbiol. 181:136-146.

Gould, L. H., E. Mungai, and C. B. Behravesh. 2014. Outbreaks attributed to cheese: Differences between outbreaks caused by unpasteurized and pasteurized dairy products, United States, 19982011. Foodborne Pathog. Dis. 11:545-551.

Greco, G., M. Corrente, V. Martella, A. Pratelli, and D. Buonavoglia. 2001. A multiplex-PCR for the diagnosis of contagious agalactia of sheep and goats. Mol. Cell. Probes 15:21-25.

International Organization for Standardization (ISO). 2004a. Microbiology of food and animal feedingstuffs-Horizontal method for the detection and enumeration of Listeria monocytogenes. Part 1: Detection method. ISO standard 11290-1:1996 and Amd. 1: 2004. ISO, Geneva, Switzerland. 
International Organization for Standardization (ISO). 2004b. Microbiology of food and animal feeding stuffs-Horizontal method for the detection and enumeration of Listeria monocytogenes. Part 2: Enumeration method. ISO standard 11290-2:1996 and Amd. 1:2004. ISO, Geneva, Switzerland.

Koop, G., S. De Vliegher, A. De Visscher, K. Supré, F. Haesebrouck, M. Nielen, and T. van Werven. 2012. Differences between coagulase-negative Staphylococcus species in persistence and in effect on somatic cell count and milk yield in dairy goats. J. Dairy Sci. 95:5075-5084.

Koop, G., T. van Wernen, N. Toft, and M. Nielen. 2011. Estimation test characteristics of somatic cell count to detect Staphylococcus aureus-infected dairy goats using latent class analysis. J. Dairy Sci. 94:2902-2911.

Koop, G., T. van Werven, H. J. Schuilling, and M. Nielen. 2010. The effect of subclinical mastitis on milk yield in dairy goats. J. Dairy Sci. 93:5809-5817.

Lam, T. J. G. M., Y. H. Schukken, J. H. Van Vliet, F. J. Grommers, M. J. M. Tielen, and A. Brand. 1997. Effect of natural infection with minor pathogens on susceptibility to natural infection with major pathogens in the bovine mammary gland. Am. J. Vet. Res. $58: 17-22$.

Leitner, G., U. Merin, Y. Lavi, A. Egber, and N. Silanikove. 2007. Aetiology of intramammary infection and its effect on milk composition in goat flocks. J. Dairy Res. 74:186-193.

Leitner, G., U. Merin, and N. Silanikove. 2004. Changes in milk composition as affected by subclinical mastitis in goats. J. Dairy Sci. 87:1719-1726.

McDougall, S., D. Malcolm, and C. G. Prosser. 2014. Prevalence and incidence of intramammary infections in lactating dairy goats. N. Z. Vet. J. 62:136-145.

McDougall, S., W. Pankey, C. Delaney, J. Barlow, P. A. Murdough, and D. Scruton. 2002. Prevalence and incidence of subclinical mastitis in goats and dairy ewes in Vermont, USA. Small Rumin. Res. 46:115-121.

Min, B. R., G. Tomita, and S. P. Hart. 2007. Effect of subclinical intramammary infection on somatic cell counts and chemical composition of goats' milk. J. Dairy Res. 74:204-210.

Moroni, P., G. Pisoni, G. Ruffo, and P. J. Boettscher. 2005a. Risk factors for intramammary infections and relationship with somaticcell counts in Italian dairy goats. Prev. Vet. Med. 69:163-173.

Moroni, P., G. Pisoni, C. Vimercati, M. Rinaldi, B. Castiglioni, P. Cremonesi, and P. Boettcher. 2005b. Characterization of Staphy- lococcus aureus isolated from chronically infected dairy goats. J. Dairy Sci. 88:3500-3509.

National Mastitis Council (NMC). 1999. Laboratory Handbook on Bovine Mastitis. NMC Inc., Madison, WI.

Nicholas, R., and S. Baker. 1998. Recovery of Mycoplasma from animals. Pages 37-43 in Methods in Molecular Biology, vol. 104. Mycoplasma Protocols. R. Miles and R. Nicholas, ed. Humana Press, Totowa, NJ.

Ohnishi, M., T. Sawada, K. Marumo, K. Harada, K. Hirose, A. Shimizu, M. Hayashimoto, R. Sato, N. Uchida, and H. Kato. 2012 Antimicrobial susceptibility and genetic relatedness of bovine Stenotrophomonas maltophilia isolates from a mastitis outbreak. Lett. Appl. Microbiol. 54:572-576.

Oliver, S. P., B. M. Jayarao, and R. A. Almeida. 2005. Foodborne pathogens in milk and the dairy farm environment: Food safety and public health implications. Foodborne Pathog. Dis. 2:115-129.

Powers, E. M. 1995. Efficacy of the Ryu nonstaining KOH technique for rapidly determining Gram reactions of food-borne and waterborne bacteria and yeasts. Appl. Environ. Microbiol. 61:3756-3758.

Rainard, P., and B. Poutrel. 1988. Effect of naturally occurring intramammary infections by minor pathogens on new infections by major pathogens in cattle. Am. J. Vet. Res. 49:327-329.

Schukken, Y. H., R. N. González, L. L. Tikofsky, H. F. Schulte, C. G. Santisteban, F. L. Welcome, G. J. Bennett, M. J. Zurakowski, and R. N. Zadoks. 2009. CNS mastitis: Nothing to worry about? Vet. Microbiol. 134:9-14.

Stuhr, T., and K. Aulrich. 2010. Intramammary infections in dairy goats: Recent knowledge and indicators for detection of subclinical mastitis. Landbauforsch. VTI AG. 4:267-280.

Valle, J., E. Gomez-Lucia, S. Piriz, J. Goyache, J. A. Orden, and S. Vadillo. 1990. Enterotoxin production by Staphylococci isolated from healthy goats. Appl. Environ. Microbiol. 56:1323-1326.

Virdis, S., C. Scarano, F. Cossu, V. Spanu, C. Spanu, and E. P. L. De Santis. 2010. Antibiotic resistance in Staphylococcus aureus and Coagulase Negative Staphylococci isolated from goats with subclinical mastitis. Vet. Med. Int. http://dx.doi.org/10.4061/2010/517060.

White, E. C., and L. S. Hinckley. 1999. Prevalence of mastitis pathogens in goat milk. Small Rumin. Res. 33:117-121.

Zhang, R., W. Huo, W. Zhu, and S. Mao. 2015. Characterization of bacterial community of raw milk from dairy cows during subacute ruminal acidosis challenge by high-throughput sequencing. J. Sci. Food Agric. 95:1072-1079. 